\title{
Philosophy for Children and the Incidence of Teachers' Questions on the Mobilization of Dialogical Critical Thinking in Pupils
}

\author{
Marie-France Daniel $^{1}$, Karima Belghiti ${ }^{2}$, Emmanuèle Auriac-Slusarczyk $^{3}$ \\ ${ }^{1}$ Université de Montréal, Quebec, Canada \\ ${ }^{2}$ Sidi Mohamed Ben Abdellah University, Fez, Morocco \\ ${ }^{3}$ U.C.A., Université Clermont Auvergne, Clermont, France \\ Email: marie-france.daniel@umontreal.ca
}

How to cite this paper: Daniel, M.-F., Belghiti, K., \& Auriac-Slusarczyk, E. (2017). Philosophy for Children and the Incidence of Teachers' Questions on the Mobilization of Dialogical Critical Thinking in Pupils. Creative Education, 8, 870-892. https://doi.org/10.4236/ce.2017.86063

Received: April 12, 2017

Accepted: May 22, 2017

Published: May 25, 2017

Copyright (c) 2017 by authors and Scientific Research Publishing Inc. This work is licensed under the Creative Commons Attribution International License (CC BY 4.0).

http://creativecommons.org/licenses/by/4.0/

Open Access

\begin{abstract}
More and more, education programs from many countries consider Critical Thinking (CT) to be an essential $21^{\text {st }}$ century competency. Our conception of CT corresponds to a socio-constructivist epistemology and the context of our research is situated in the Philosophy for Children approach. This text presents a study, in which we compared results from two exchanges, one which was conducted with closed anecdotal-type questions, and the other with open philosophically-oriented questions. The analysis tool was the operational model of the developmental process of Dialogical Critical Thinking (DCT), developed and validated in previous studies. Participants were five groups of Moroccan pupils aged 10 to 15 years. Results indicate that in the exchange conducted with closed anecdotal-type questions, the overall epistemology of groups of pupils aged 10 to 15 years was simple, and the dominant epistemological perspective was post-egocentricity. In the exchange conducted with open philosophically-oriented questions, the overall epistemology for the majority of pupil groups was simple with a tendency toward a complex epistemology, and the dominant perspective for the majority of groups was relativism.
\end{abstract}

\section{Keywords}

Questioning Techniques, Dialogical Critical Thinking, Epistemological Perspectives, Primary and Secondary School, Philosophy for Children, Teaching Methods

\section{Introduction}

In contemporary industrialized societies, education is increasingly oriented toward neo-liberalism. The underlying values are, among others, problem-solving, economic reasoning, competitiveness, efficiency and profitability (among others: 
Fabre \& Gohier, 2015; Lenoir, 2016).

However, our position is situated in a perspective which some refer to as social-constructivist (for a definition, see Meyer et al., 2003; Wertsch, 1997), according to which the school's responsibility is to guide pupils toward the shared construction of their knowledge and skills with collective and individual emancipation in mind (Dewey, 1983'; Freire, 1970). In this view, educational goals should be oriented toward the development of ethics and collective citizen consciousness (among others: Lenoir, 2016). As a corollary, education programs should emphasize transversal and disciplinary competencies that are likely to stimulate within pupils' values associated in particular with questioning, dialogue and critical thinking (CT).

As to CT, it is not defined consensually. Most conceptions of CT are rooted in a technicist perspective, that is, $\mathrm{CT}$ is reduced to teaching/learning the rules of formal logic, and its evaluation occurs through individual tests that measure the pupils' skills associated with the proper application of these rules (Kwack, 2007; Lenoir, 2016; Winstanley, 2008). Other conceptions of CT are oriented toward humanistic values. These are expressed through an intra-subjective reflection focused on understanding others-which could, when pushed to its limit, lead to an unconditional acceptance of what others say, and in so doing lead to a relativist reflection in the absolute sense of the term, leaving a moral and intellectual vacuum (Bourdon, 2008; Bourgeault, 2012; Tardif, 2012). Finally, some conceptions of CT are rooted in a social-constructivist perspective, that is, these conceptions are oriented toward emancipation of people and societies through critical dialogue among peers (Freire, 1970). These conceptions emphasize responsible CT that can help youngsters understand others, the world and the pluralism in which they are to live and act (see Bourdon, 2008; Leroux, 2016: chap. 2). It is this type of CT that is recognized by international entities such as UNESCO (2015) and is aligned with international conventions such as the Convention on the Rights of the Child, which was ratified in 1990 by a majority of countries around the world (among others: Butler, 2012). However, to get engaged in a social-constructivist conception of CT implies, for both teachers and pupils, a commitment on various levels (cognitive, emotional and social) that is seen as demanding and even repugnant to some (see Kpazaï, 2015).

To stimulate in pupils CT that is based on interactions and social commitment, several strategies have been proven effective in classrooms, including: dialogue within a community of inquiry, metacognitive reflection, reflective writing, mind-mapping, guided cooperative questioning, critical questioning (among others, Galichet, 2002, 2012; King, 1994; Lacroix, 2010; Lipman et al., 1980; Marceau, 2010; Melo-Leon, 2015; Michalko, 2006; Tallent \& Barnes, 2015).

In this paper, we focus more specifically on the questioning strategy. We explore the question: What is the impact of teachers questions on the mobilization of Dialogical Critical Thinking in pupils? Firstly, we present a brief review of the

${ }^{1}$ The educational principles of pragmatist philosopher John Dewey are at the very foundation of the social-constructivist epistemology (see Daniel \& Fiema, in press). 
literature examining types of questions (closed and open) and their impact on the cognitive development in youngsters. Secondly, we describe the Philosophy for Children approach, which constitutes the context of our study. Thirdly, we describe the methodology and introduce the tool that was used for the comparative analysis of both exchanges among pupils, namely the model of the developmental process of what we name "Dialogical" CT (DCT). Fourthly, we present our results. Finally, in the discussion, emphasis is on the importance and difficulty of stimulating DCT in pupils with open philosophically-oriented questions as well as the necessary praxis of questioning within teacher education programs, and we suggest questions that are likely to stimulate DCT within pupils.

\section{Teachers' Questioning}

Ever since Socrates, teacher questioning has been an integral part of teaching. The pedagogical literature suggests different approaches to classifying teacher questions. In this text we focus on closed and open questions.

\subsection{Closed Questions}

Studies conducted over the past decades in the United States show quite consistently that closed questions are favoured by teachers because they do not disturb order in the classroom, and because they leave the teacher in charge of verbal interactions (see Bressoux et al., 2002; Bressoux \& Dessus, 2003). Closed questions are manifested in various forms: some are conducive to answers of a "yes or no" or "true or false" type; others present pupils with interrogative options (i.e.: choosing the correct answer among two options provided by the teacher). Another form of closed question that is frequently used in classrooms is tied to monitoring pupil learning. These questions converge toward a single and expected answer; they require pupils to remember a particular fact or to transfer information in a predictable manner anticipated by the teacher (among others: Margutti, 2006; McComas \& Abraham, 2004; Schwarz \& Slakmon, 2015).

To the list of closed questions found in the literature, we add closed questions that are anecdotal. This type of questions supposes that teachers ask pupils concrete questions that are centered on personal anecdotes (e.g.: What are your favorite animals? What did you do yesterday?). These questions may be considered open by some, because they include various possible answers; however we consider them closed, because they refer to a personal opinion, feeling or memory. This type of question constitutes a limiting factor for the group's reflection in that it elicits a detail from a pupil's experience, and thus leads an answer which can neither be completed nor generalized by the pupil's peers. In short, we consider anecdotal questions as closed since they elicit a narrow scope of answers and do not lead to a shared construction of a common point of view (see Dewey, 1960; Gadamer, 1990 quoted by Weber \& Wolf, 2017).

\subsection{Open Questions}

Open questions are questions that transcend specific information and generalize 
situations, experiences and concepts. In this sense, open questions presuppose various contexts in which the concepts may be used (Weber \& Wolf, 2017). Open questions are complex and often divergent (McComas \& Abraham, 2004). Although related to pupils' interests, they explicitly contain a challenge (Critelli \& Tritapoe, 2010). Open questions can be directed to a pupil or to a group. In the latter case, all of the pupils are considered potential answerers; together they participate in the construction of knowledge through verbal interactions. However, dialogical interactions among peers are rarely observed in classrooms, even though scientific studies recognize their merit in pupil learning (Martin \& Hand, 2009). One of the reasons could be lack of teacher formation in open questioning or lack of time for this type of activity (Martin \& Hand, 2009). Another reason could be that open questions create a more disconcerting environment for pupils when compared to closed questions since the pupils either cannot or can hardly predict them (Margutti, 2006).

It should be noted that although open questions are complex, they are not all critical (King, 1994; Smith \& Szymanski, 2013)—which is explicitly aimed by open philosophically-oriented questions. Indeed, the latter aim at stimulating in pupils appreciative judgments, position taking and evaluation. Open philosophically-oriented questions are related to a problem that is likely to generate cognitive conflicts in pupils' minds. Open philosophically-oriented questions do not look for the truth but for a diversity of meanings.

\subsection{Impact of Questions (Closed and Open) on Pupils' Cognitive Development}

In the late 1980s and early 1990s, research showed that closed questions were more appropriate to elementary school pupils than open questions, and that in elementary and secondary classrooms, a combination of open and closed questions was more effective to stimulate cognitive skills than exclusively using one or the other type of question (for a compilation, see Cotton, 1988). These researches also indicated an absence of interdependence between the complexity of a question and the complexity of an answer. In other words, they indicated that whether questions were open or closed had no significant impact on the complexity of pupil answers (Arends, 1994; Cotton, 1988; Wilen, 1991).

On the other hand, several recent studies show that a close correlation does exist between the types of questions posed and the nature of the associated answers. These research results demonstrate that closed questions stimulate simple thinking skills associated in particular with memorization and comprehension of curriculum content within pupils (among others: Curenton, 2016; Smith \& Szymanski, 2013; Margutti, 2006), whereas open questions foster various complex thinking skills and attitudes within pupils ${ }^{2}$. For example, in a study recently conducted with Moroccan engineering students, the fact that teachers used questioning as one of the activities to trigger students' CT was seen to encourage ${ }^{2}$ Based on Bloom's taxonomy, there exists a consensus in the literature on associating enunciation, identification, memorization, etc. to simple thinking skills, and analysis, reasoning, divergent relationships, argumentation, synthesis, evaluation, etc. to complex thinking skills (among others: Gallagher \& Aschner, 1963; Smith \& Szymanski, 2013). 
students "to reflect on each other's answers and opinions...to express their point of view...to answer open-ended questions, and to try to investigate and explore other possibilities" (Belghiti et al., 2016). Results of other studies also establish that open questions guide pupils toward rigorous thinking and well thought-out decisions (among others: Ali-Sheir et al., 2014; Brookhart, 2016; Buckley et al., 2015; Colley \& Windchiti, 2016; Fasco, 1994; Francis, 2016). Open questions motivate pupils to actively participate in a discussion and to understand peer statements and lessons taught by the teacher (King, 1994; Melo-Leon, 2015; Smart \& Marshall, 2013), stimulate divergent thinking and elicit a variety of answers that enable pupils to extrapolate, to create new relationships and to consider new points of view (Smith \& Szymanski, 2013; King, 1994; McComas \& Abraham, 2004).

Finally, concerning teacher's questions within the specific framework of pupils discussions, several authors maintain that in order to stimulate the reflection process within an exchange, it is necessary to question pupils in order to create doubt or cognitive conflict in pupils' mind or, in other words, to create a rift in their certainties (among others: Dewey, 1960; Sorsana \& Troadec, 2007). However, questioning pupils to unsettle their certainties is interpreted by some researchers and educators as an anti-pedagogical action in that it interrupts the construction of a personal point of view and represents an unnecessary constraint on the pupil (Ikuenobe, 2001; Levine et al., 2004). Finally, to other authors, teacher's questioning indeed remains a constraint, but a necessary constraint in that it enables the emergence of thinking. They explain that interrupting with questions destabilizes pupils' representations and, in so doing, leads to problematizing ideas and to more sustained argumentation. In short, to these authors, interruption by questioning leads to a process of critical inquiry that results in a more complex resolution of the problem posed or a more refined representation of the concept being discussed (Barth, 2008; Berland \& McNeill, 2010; Golding, 2009; Haynes \& Murris, 2011; Karabulut, 2012; Martin \& Hand, 2009).

In this text: a) we examine two types of questions that are not much covered in the pedagogical literature, namely "closed anecdotal-type" questions and "open philosophically-oriented" questions; b) the criterion selected to evaluate their respective impact on stimulating CT in pupils goes beyond thinking skills per se to focus on the "epistemological complexity" of pupils' interventions, as we consider $\mathrm{CT}$ a process rather than a final outcome (a description of epistemological perspectives is provided below); c) the pedagogical context in which our study was conducted is the Philosophy for Children (P4C) approach (described in the next section).

\section{Philosophy for Children}

P4C was proposed in the 1970s by American philosopher Matthew Lipman. Lipman and his colleagues (Lipman, Sharp, \& Oscanyan, 1980) believe that if schools develop active pupils who question their personal and social experience, pupils will in turn create conditions conducive to critical questioning, emancipa- 
tion and democratization (see also Dewey, 1960, 1983; Gregory, Haynes, \& Murris, 2017). Thus, the objective of $\mathrm{P} 4 \mathrm{C}$ is to stimulate in pupils a type of CT that enables them to solve common problems in collaboration with their peers. In $\mathrm{P} 4 \mathrm{C}$, critical reflection is not theoretical; it takes root in pupils' personal and social experience, and it aims at the improvement of this experience. Questioning, which is at the heart of $\mathrm{P} 4 \mathrm{C}$, occurs in teacher-pupil interactions just as in interactions among peers and in a pupil's internal deliberations (Kohan, 2004; Murris, 2013; Weber \& Wolf, 2017).

\subsection{Application}

To implement P4C in the classroom, Lipman and his colleagues (1980) suggest three steps: 1) Reading a philosophical text or other discussion catalyst; 2) Collecting pupils' questions; 3) Conducting a dialogue within the community of inquiry.

Catalyst. The catalyst can be a philosophical text adapted to the pupils' age; it can be associated with any material (e. g.: images, photographs, works of art, music, films) as long as it introduces paradoxes and ambiguities and brings pupils to question ideas. Originally, Lipman and colleagues suggested a philosophical novel. The novel is considered philosophical if it contains open concepts that are likely to captivate pupils' intellectual curiosity. Pupils take turns reading the text out loud. This activity is important to instill peer cooperation; it constitutes a first active involvement in the community of inquiry. Pupils are no longer receptacles who receive narrative data, they become active participants in a common reading.

Collecting questions. Next, pupils are invited to ask questions regarding ambiguous situations or concepts inherent in the text or other catalyst that they would like to discuss. Formulating questions is a fundamental step, on one hand because it presupposes that pupils are engaging in an autonomous reflection process and that they are making an effort to understand the catalyst in a critical manner. On the other hand, formulating questions is fundamental because it implies pupil co-responsibility in the philosophy sessions: through their questions, the pupils rather than the adult decide on the theme of the exchange. Formulating questions is also a gratifying step for pupils since "the right to ask questions" which usually belongs to the teacher, is transferred to them. The vertical power structure (teacher-pupils) becomes horizontal, and the principle of equality among participants advocated by $\mathrm{P} 4 \mathrm{C}$ finds its coherence. In sum, formulating questions implies that pupils are persons-who-think-and-question.

Philosophical dialogue within a community of inquiry. In order for pupils to find meaningful answers on their own to the questions they have posed, the teacher guides them toward a philosophical/critical dialogue within the community of inquiry. The community of inquiry is a cooperative environment in which pupils can feel motivated and comfortable in expressing their doubts, their points of view and their disagreements. The community of inquiry is fundamental, in that the philosophical questions the pupils attempt to answer do 
not presuppose a single correct answer prefabricated by adults and to be found in textbooks, but are rather sufficiently complex to require the group's input to solve them. The community of inquiry requires and encourages interactions among peers and stimulates skills and competencies on the cognitive, emotional and social levels.

As for the dialogue, it is synonymous neither with verbal sparring nor with simple conversation. Studies conducted with pupils aged 4 to 12 years have brought to light a philosophical dialogue learning process in pupils who experimented with $\mathrm{P} 4 \mathrm{C}$ during an entire school year. At the beginning of philosophical praxis, the exchange is anecdotal with pupils speaking in a non-structured manner about specific and personal situations. The exchange can also be monological with pupils entering into a process of inquiry essentially oriented toward a quest for "the" correct answer. After several months of praxis, it was observed that the exchange becomes non-critical dialogical, which is manifested when all of the pupils together are involved in the construction of knowledge or representations, without, however, considering the need to evaluate peer points of view or the validity or viability of the criteria or issues at stake. The exchange is semi-critical dialogical when certain pupils express disagreement or criticism without influencing their peers' points of view. By the end of the school year, we sometimes observe a critical dialogical exchange, which is characterized by reciprocity, openness to divergence and intersubjectivity. Critical dialogue is not the rhetorical argumentation of a previously constructed point of view nor a competitive debate; it consists of looking for meanings within a community of inquiry aimed at the improvement of the individual and social experience (Daniel, 2000; Daniel \& Delsol, 2005; Daniel et al., 2011).

\subsection{Teachers' Questions in P4C}

To stimulate pupils' critical dialogue and to transform the classroom into a community of inquiry, Lipman and colleagues (1980) favour the Maieutic Socratic approach since, as a holistic learning philosophy, it involves dialogue, questioning and caring evaluation. They suggest that teachers ask pupils philosophical questions. Indeed they believe that children are natural philosophers and, as such, that this type of question should foster their curiosity and start their reflective process.

Moreover, following Vygotsky, Lipman argues that the philosophical questions teachers ask may become a thinking model for pupils, who will gradually come to ask themselves and their peers this type of question (Lipman, 2003). This has been corroborated by linguists who have shown that the syntax of teacher's questions gives rise to this specific discursive and syntactic form in pupils (Rispail, 2007) and that the teacher's judgment abilities become integrated into the pupils' thinking modes after some six months of philosophical praxis (Auriac-Peyronnet \& Daniel, 2002).

A philosophical question is defined by Dewey as a conceptual "problem" rather than a simple "question". Generally, a simple question is specific and strives 
for a unique and conclusive answer. On the other hand, a philosophical question is likely to generate cognitive conflicts in pupils' minds; it is oriented toward a resolution that will be subjected to revision (Dewey, 1960). Lipman and colleagues specify that a question carries philosophical meaning when it questions concepts, develops around causes and consequences, calls into question achievements, traditions and biases, searches for justifications, valid criteria, nuances or relationships between concepts, etc. (Lipman et al.,1980).

\subsection{Variants of P4C}

Over the past decades, several variants of the Lipmanian approach have put forward diverse objectives and facilitation styles (see UNESCO, 2007). In these variations, the teacher's objectives can center primarily on one level or another (cognitive or social or emotional). Also, the teacher's type of facilitation in a session might vary on a continuum that ranges from very guided to fairly passive. In passive facilitation, the teacher respects pupils' development but without stimulating any transcendence of viewpoints; the teacher's role thus consists in listening without asking pupils any questions. In a guided approach to facilitation, questioning gains in importance in that the aim of philosophical sessions is for pupils to progress in their learning. Here also, the types of questions posed by teachers vary according to the intended objective (Auriac-Slusarczyk \& Colletta, 2015).

Diversity of approaches is necessary in that it addresses the various contexts in which philosophical praxis takes place and, in so doing, better addresses the diversity of pupils' experiences and needs. Nevertheless, we feel it is appropriate to verify whether, with regard to approaches aimed at developing CT in pupils, the teacher's questions attain their objective. Indeed, although studies that fall within the Lipmanian perspective mention the fundamental contribution of questioning to the development of logical reasoning in pupils, or to the development of CT in Higher Education (Golding, 2011), to the best of our knowledge, no study has compared the respective impacts on two exchanges conducted in elementary and secondary school classes-one based on closed anecdotal-type questions and the other based on open philosophically-oriented questions-on stimulation of pupils' DCT and, more specifically, on stimulation of the epistemological perspectives inherent in DCT.

\section{Methodology}

The study we present in this text is a comparative study developed according to a qualitative paradigm. It is part of a research project on DCT within groups of pupils aged 10 to 19 years in three locations: Morocco, France and Quebec. The project was subsidized by the Social Sciences and Humanities Research Council of Canada (\#435-2013-0212). A certificate of ethics was delivered by Université de Montréal (CPER-13-030-D).

The sample population selected for this study consisted of five groups of Moroccan pupils aged between 10 to 15 years old. These pupils were randomly cho- 
sen from two public schools in Rabat. They were also selected from two levels of education. The first two groups of pupils were selected from a primary school. At this school, two groups of pupils, belonging to the $5^{\text {th }}$ grade (aged 10 to 11 years old) and the $6^{\text {th }}$ grade (aged 11 to 12 years old), participated in the exchanges. The other three groups that participated in the exchanges included pupils from the first year (pupils aged 12 to 13 years old), second year (aged 13 to 14 years old) and third year (aged 14 to 15 years old) of a secondary school. There was an average of 30 pupils per group.

Two 45 to 60 minutes exchanges per class were recorded on audiotape and then transcribed verbatim, for a total of 10 verbatim and 3,891 pupil interventions.

Both exchanges focused on the same theme: "What does it mean to be free?" Both exchanges included closed and open questions, since $\mathrm{P} 4 \mathrm{C}$, while it aims at philosophical reflection, remains related to pupils' experiences and interests (see Buckley et al., 2015). Nevertheless, the first exchange was mainly characterized by closed anecdotal-type questions (e.g.: “... For you, being free is to play on your computer...at what do you play exactly?"). The second exchange was mainly characterized by open philosophically-oriented questions (e.g.: "On what are you basing your point of view?"; "What do you mean by ...?"; "Who can build on and clarify this idea?”; “... Who can suggest a different idea ...?”).

Both exchanges were animated by the same facilitator, and took place a few days apart. To make sure that the first exchange did not constitute training for pupils to develop their epistemologies, we conducted a similar study in Quebec and France, in which two exchanges were conducted a few days apart on the same theme. In the latter two locations, the facilitators' questions were identical in both exchanges (mainly open philosophically-oriented questions). Analysis of the verbatim transcripts revealed that in the second exchange, the epistemology of pupils in Quebec and France was quite similar to that of the first exchange. In other words, these results indicate that a single exchange is not sufficient to influence or modify the pupils' epistemologies. This ensures the reliability of our results concerning the impact of the type of question on the epistemological mobilization of the pupils.

As a first step, all verbatim interventions were coded by one of the team's researchers. As a second step, the interventions were all blind re-coded by a different researcher. If there was disagreement about the codes, a discussion was held until both researchers reached a consensus.

\section{Analysis Tool:}

The tool used to analyze the verbatim transcripts was the operational model of the developmental process of Dialogical Critical Thinking (DCT), which comprises four thinking modes with six epistemological perspectives ${ }^{3}$ (see the analysis grid in Appendix A).

\footnotetext{
${ }^{3}$ Based on the Grounded Theory methodology, a model of the developmental process of DCT emerged from our previous research projects conducted with pupils aged 4 to 12 years in Quebec, Ontario, France, Australia and Mexico. These research projects were funded by the Social Sciences and Humanities Research Council of Canada (SSHRC).
} 
First, the analysis grid allows us to determine which thinking modes are manifested in pupils' discourse as they exchange with their peers: The mode is logical when the pupil's intervention reflects coherence. It is creative when it reflects novelty and divergence. It is responsible when it refers to social and ethical rules, principles and values. And it is metacognitive when it reflects thinking concerning peers' and one's own points of view.

Second, the analysis grid allows us to determine whether pupils' thinking (as manifested in their interventions) is simple or complex by referring to six epistemological perspectives: In egocentricity, pupil interventions remain anecdotal, concrete and specific (e.g.: I, myself ...). In post-egocentricity, pupils' interventions are concrete, but they become slightly distanced, since they begin to include their relatives (e.g.: My brother, he ...). In pre-relativism, pupils' interventions become more general, but remain concrete and descriptive (e.g.: Friends, they are ...). In relativism, pupils' interventions manifest themselves in convergent relationships between their statements and those of their peers (e.g.: I agree with ...) and they manifest empathy (e.g. We should take care of ...). In post-relativism/pre-intersubjectivity, pupils' interventions manifest themselves in more complex relationships, as they are divergent (e.g.: I do not totally agree with your idea because...) and they concern a distant environment (e.g.: Children from another country). In intersubjectivity, pupils' interventions manifest themselves in the collaborative construction of relationships that are complex and evaluative, aiming at the improvement of a common good (e.g.: School, society, the planet) (see Daniel et al., 2005; Daniel \& Gagnon, 2011).

\section{Results}

Other than the fact that the groups of pupils' epistemologies remains relatively stable from the end of elementary to the end of secondary school ${ }^{4}$, results show that on an epistemological level (including the four thinking modes): in the exchange conducted with closed anecdotal-type questions, the dominant perspective in the majority of pupil groups is post-egocentricity (see Table 1), which indicates that pupil interventions are comprised of units (not relationships) centered on specific and concrete events experienced by pupils or those close to

Table 1. Epistemologies mobilized using closed anecdotal questions.

\begin{tabular}{cccccc}
\hline Age group/Epistemological Perspective & $\begin{array}{c}10-11 \\
\text { years }\end{array}$ & $\begin{array}{c}11-12 \\
\text { years }\end{array}$ & $\begin{array}{c}12-13 \\
\text { years }\end{array}$ & $\begin{array}{c}13-14 \\
\text { years }\end{array}$ & $\begin{array}{c}14-15 \\
\text { years }\end{array}$ \\
\hline Egocentricity & $22 \%$ & $37 \%$ & $30 \%$ & $24 \%$ & $16 \%$ \\
Post-Egocentricity & $32 \%$ & $39 \%$ & $34 \%$ & $28 \%$ & $31 \%$ \\
Pre-relativism & $23 \%$ & $16 \%$ & $25 \%$ & $30 \%$ & $27 \%$ \\
Relativism & $21 \%$ & $9 \%$ & $10 \%$ & $17 \%$ & $26 \%$ \\
Post-relativism/pre-intersubjectivity & $2 \%$ & $0 \%$ & $0 \%$ & $1 \%$ & $0 \%$ \\
Intersubjectivity & $0 \%$ & $0 \%$ & $0 \%$ & $0 \%$ & $0 \%$ \\
\hline
\end{tabular}

${ }^{4}$ We will further study this aspect of the question in another paper. 
Table 2. Epistemologies mobilized using philosophical questions.

\begin{tabular}{cccccc}
\hline Age group/Epistemological Perspective & $\begin{array}{c}\mathbf{1 0 - 1 1} \\
\text { years }\end{array}$ & $\begin{array}{c}11-12 \\
\text { years }\end{array}$ & $\begin{array}{c}\mathbf{1 2 - 1 3} \\
\text { years }\end{array}$ & $\begin{array}{c}\mathbf{1 3}-\mathbf{1 4} \\
\text { years }\end{array}$ & $\begin{array}{c}\mathbf{1 4}-\mathbf{1 5} \\
\text { years }\end{array}$ \\
\hline Egocentricity & $1 \%$ & $2 \%$ & $4 \%$ & $3 \%$ & $0 \%$ \\
Post-Egocentricity & $31 \%$ & $24 \%$ & $29 \%$ & $28 \%$ & $15 \%$ \\
Pre-relativism & $20 \%$ & $33 \%$ & $\mathbf{3 8 \%}$ & $32 \%$ & $18 \%$ \\
Relativism & $\mathbf{4 6 \%}$ & $\mathbf{4 0 \%}$ & $29 \%$ & $\mathbf{3 8 \%}$ & $\mathbf{5 9 \%}$ \\
Post-relativism/pre-intersubjectivity & $1 \%$ & $0 \%$ & $0 \%$ & $0 \%$ & $8 \%$ \\
Intersubjectivity & $0 \%$ & $0 \%$ & $0 \%$ & $0 \%$ & $0 \%$ \\
\hline
\end{tabular}

them, and the interventions are not justified.

Here is an example of a post-egocentric intervention in the group of $10-11$ years old: I find my freedom in playing with my friends.

Here is an example of a post-egocentric intervention in the group of $14-15$ years old: For me, freedom is to go out with my friends when I want and where I want.

In the exchange conducted with open philosophically-oriented questions, the dominant perspective in the majority of groups is relativism (see Table 2), which indicates that pupil interventions are formulated with convergent relationships between their peers and their own points of view, that the points of view are characterized by empathy, and are somewhat generalized and justified with concrete reasoning.

Here is an example of relativist intervention in the group of 10 - 11 years old when pupils were discussing freedom of expression: If the pupil did not answer correctly it is because he does not know, he had not understood even if the teacher had maybe explained before. The other should not laugh at him and if he talks with him (...) he should tell him it is by making mistakes that we learn.

Here is an example of relativist intervention in the group of 14 - 15 years old: The concept of freedom is found in peace, which guarantees us not to be exposed to harassment. Thus the boy and the girl in the family would be equal and if there is a peaceful environment the girl will be able to go out as she wishes and get back home when she wishes without being harassed. And even if a boy goes out with a girl this means they would respect each other and they would respect their environment.

It is also significant to note that in the exchange conducted with closed anecdotal-type questions, the percentages for egocentricity were relatively high (between $16 \%$ and $37 \%$ of interventions), and in the exchange conducted with open philosophically-oriented questions, the percentages for the same epistemological perspective were almost zero (between $0 \%$ and $4 \%$ of interventions). In both exchanges, few or no interventions were observed in the post-relativism/pre-intersubjectivity perspective and no intervention was noted in the intersubjectivity perspective.

Furthermore, because DCT is a dynamic process (vs. a final product), the re- 
sults should also take into account the movement reflected in the epistemological perspectives as a whole. This movement develops like a "scaffolding" process, in other words, it implies a recursive variation between simple and complex perspectives, it advances and retreats until learning is stabilized. More specifically, it brings to light: a) learning that is about to be appropriated by pupils and that is manifested in the perspectives that precede the dominant one, b) learning that is appropriated and that is manifested in the dominant perspective, c) learning that is about to be acquired; it indicates that an epistemological transformation is taking place within the groups of pupils and this is manifested in the perspectives that follow the dominant one (Daniel \& Gagnon, 2011).

To take into account this scaffolding process, we divided the percentages relating to the perspectives into two groups according to whether they applied to simple or complex perspectives. The perspectives of egocentricity, post-egocentricity and pre-relativism are considered simple in that they reflect representations marked by concreteness and centering. Relativism, post-relativism and intersubjectivity are considered complex in that they reflect representations marked by generalization/abstraction and decentering.

Figure 1 and Figure 2 show that in both exchanges (the first with closed anecdotal-type questions and the second with open philosophically-oriented questions), the percentage of interventions displaying simple epistemological perspectives remains predominant except in the group of 14 to 15 years old, where the complex epistemology dominates when the exchange is conducted with open philosophically-oriented questions. Nevertheless, when we consider the disparity between each group of pupils, it becomes apparent that in the exchange centered on closed anecdotal-type questions (see Figure 1), the gap between the simple and complex epistemologies in the groups of pupils is large, varying from $48 \%$ to $83 \%$. This gap indicates that pupil interventions are mostly rooted in simple epistemologies (pre-relativism, post-egocentricity or egocentricity).

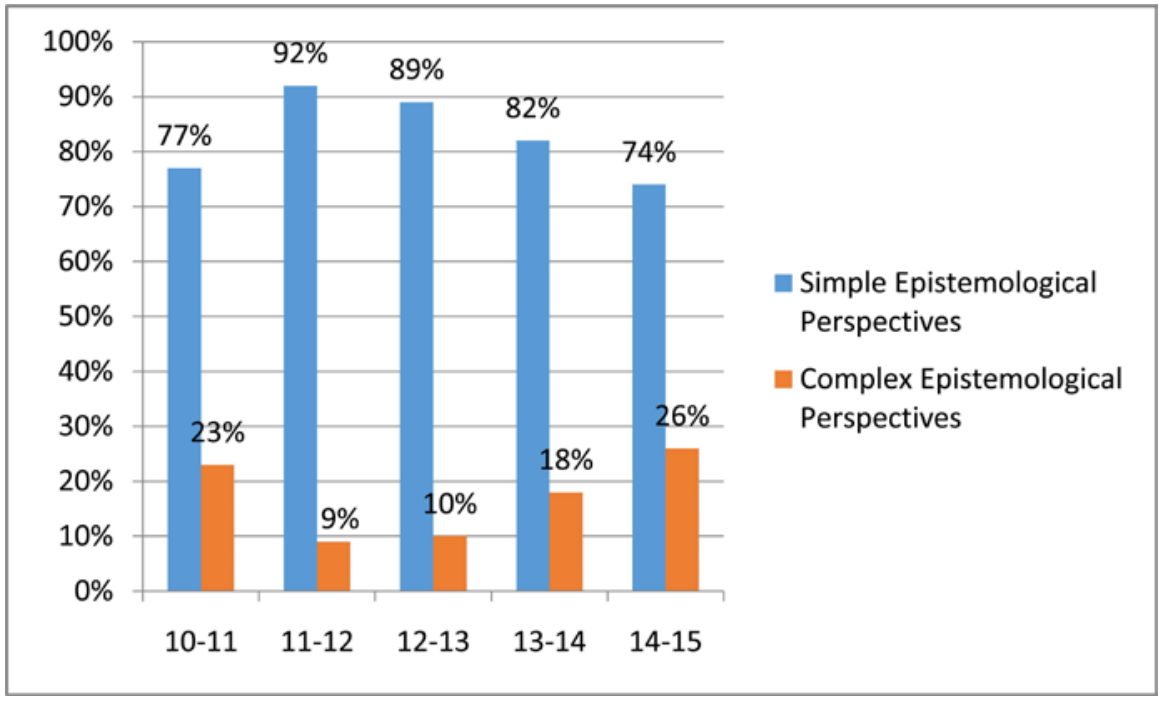

Figure 1. Grouped perspectives-closed anecdotal-type questions. 


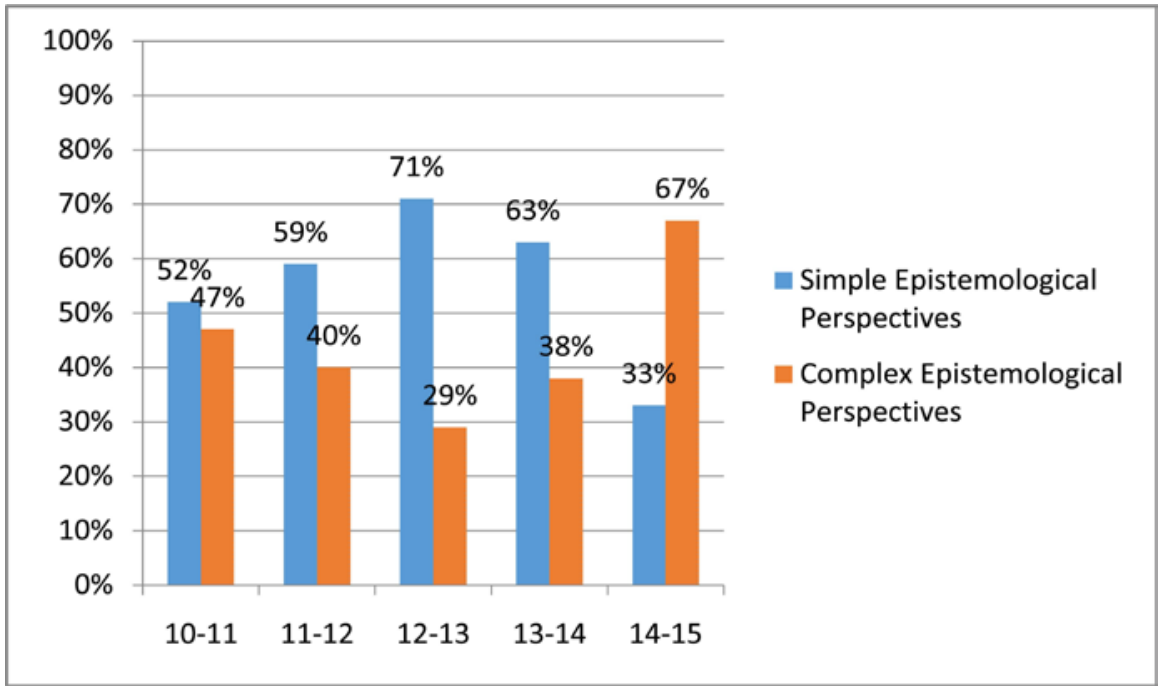

Figure 2. Grouped perspectives-open philosophically-oriented questions.

Whereas in exchanges centered on open philosophically-oriented questions (see Figure 2), the gap between the simple and complex perspectives is significantly less (between 6\% and $42 \%$ ) in four groups out of five, and is even reversed in the group of $14-15$ years old $(-34 \%)$, in which the complex epistemologies dominate. The reduced disparity indicates that, thanks to the use of open philosophically-oriented questions, simple epistemologies are about to be surpassed (relativism has already been integrated in four of the five groups), even though the complex perspectives have not yet been appropriated.

In sum, results from the first analysis confirm the point of view of some authors, according to whom pupil interventions are closely linked to the types of questions teachers pose (among others: Curenton, 2016; Smith \& Szymanski, 2013; Margutti, 2006). More specifically, this analysis shows that, in a context of exchanges among pupils, teachers' questions have an observable incidence on the epistemological complexity of groups of pupils. In other words, closed anecdotal-type questions stimulate simple representations centered on personal experience and concreteness in pupils, whereas open philosophically-oriented questions encourage complex representations characterized by decentering, willingness to listen to others and generalization of viewpoints.

Results of the second analysis indicate, on one hand, that open philosophically-oriented questions activate a process of increasing epistemological complexity of DCT. On the other hand, this analysis shows that this process, far from constituting "ready-made thinking", represents a "thinking-with-others" mode that develops with time and praxis.

\section{Discussion and Conclusion}

These results lead us to insist-if the goal is to stimulate/develop DCT within pupils-on the importance of asking open philosophically-oriented questions within the context of sustained (once per week) and regular (during at least one entire school year) dialogical critical praxis. In the following pages, we emphas- 
ize: a) the difficulty for teachers and pupils to engage in a dialogical critical exchange based on open philosophically-oriented questions; b) the necessity to add a praxis of questioning within teacher-education programs. Finally, we suggest questions that are likely to stimulate DCT in pupils.

\subsection{Type of Exchange and Intersubjective Reflection}

One of the conditions to favour a dialogical critical exchange and stimulate DCT in pupils is, for the teacher as well as the pupils, to agree to reflect on what they do not know (Schwarz \& Slakmon, 2015). Then the teacher must ask critical questions and allow pupils to present arguments, multiple, diverse and unexpected points of view, even allow them to express constructive criticism (Martin \& Hand, 2009; Tallent \& Barnes, 2015). However, the pedagogical literature shows that, for the teacher, it is easier and more reassuring to facilitate an exchange by asking closed questions that will lead pupils to relate personal anecdotes or to identify facts from textbooks or to endorse the teacher's own personal beliefs or knowledge (Margutti, 2006; McComas \& Abraham, 2004; Martin \& Hand, 2009; Smith \& Szymanski, 2013). Among possible reasons for this, let us note the fact that teachers may either lack self-confidence because of a lack of practice in this activity or, on the contrary, are over-confident because they feel they often "talk" with their pupils (Chesters \& Hinton, 2017). Also, worth mentioning is the inertia of the culture of compliance that thrives in schools (Baumfield, 2017; El Kirat \& Belghiti, 2014).

Parallel to this, observations in classrooms of pupils aged 10 to 15 years indicate that talking about oneself and personal experience is more popular than reflecting on philosophically-oriented questions. Participating in an anecdotal exchange is more fun and less demanding than engaging in critical dialogue because the dialogical exchange that is mobilized and ensues from critical questions is likely to confront pupils with the unknown, with uncertainty about the correct answer, even with their own errors in judgment, their beliefs and their ignorance. The dialogical exchange implies that pupils must subsequently reconstruct their opinions, judgments, values, etc. (see Weber \& Wolf, 2017).

In spite of this, some researchers and teachers consider that a narrative or anecdotal exchange (conducted with closed questions) is by no means insignificant, in that it allows pupils to share with others, to reminisce, to become aware of their emotions, aware of their intentions. Thus, the anecdotal or narrative exchange would give meaning to pupils' everyday experiences (among others: Bouchard, 2002; Chesters \& Hinton, 2017; Nussbaum, 2004). Along with some other researchers, we consider that this type of exchange is nevertheless likely to engender a superficial reflection, an "empty shell" that does not serve to improve individual nor social experience (Tardif, 2012). All the more so since the human brain has a tendency to make errors, to fabricate biases and to preserve original beliefs rather than self-question and self-correct (Buckely et al., 2015).

Therefore, we believe that dialogical critical exchange is desirable because it underpins an intersubjective reflection process that is oriented toward improv- 
ing the individual and social experience (see Daniel \& Gagnon, 2016).

\subsection{Teacher Education Programs}

The scientific literature indicates that if, on one hand, experienced teachers lack practice to efficiently make the transition from their role as information transmitters to that of facilitators (Auriac-Peyronnet \& Daniel, 2009; Chesters \& Hinton, 2017; Martin \& Hand, 2009), on the other hand, novice teachers and future teachers lack adequate training in this field.

In major reports from the Association of American Colleges and Universities, we note that a number of students enrolled in teacher education programs in universities have neither learned to develop nor to use complex thinking skills (AACU, 2002, 2007). In Quebec, France and Morocco, the authors concur that, by the end of their initial training, the discourse of teachers is consistent with simple epistemologies (Belghiti et al., 2016; El Kirat \& Belghiti, 2014; Forges, 2013; Lechasseur, 2015; Pettier, 2015). Studies explain that teachers' exposure to a type of instruction that fosters memorization over thinking and questioning affects the teachers' perceptions of what CT is, as well as the teaching practices they opt for in their classes, and thus affect the extent to which these teachers can develop their students' CT (El Kirat \& Belghiti, 2014; Belghiti et al., 2016). Nevertheless, interacting with pupils can be learned (Auriac-Peyronnet \& Daniel, 2009).

In that sense, a number of suggestions have been put forward, including reintroducing philosophy in teacher education programs (Chesters \& Hinton, 2017) and regularly exposing teachers to in-depth questioning (AACU, 2002, 2007; Martin \& Hand, 2009; Smith \& Szymanski, 2013). In these cases, praxis is fundamental since questioning and reflecting critically is not just a tool or a method that is transmitted or acquired theoretically; it implies an active engagement on the part of the teachers, an engagement that involves a transformation of their own epistemological perspectives. This epistemological transformation presupposes and develops the intellectual habit of clarifying and justifying the theses, actions and situations that are an inherent part of their learning and their everyday experiences (logical mode); it develops the intellectual habit of questioning, (re)-defining and suggesting solutions in order to improve them (creative mode); it develops the intellectual habit of evaluating the consequences of their decisions on pupils, on their school and on their society (responsible mode); and the habit of self-correcting when necessary (metacognitive mode). As a corollary, if future teachers integrate these intellectual habits during their education programs, as practicing teachers they will be able to transform their classroom into a community of inquiry in which the learning of many school subjects would be furthered thanks to critical questioning and dialogical praxis (see Baumfield, 2015, 2017)—which should be part of the professional and civic responsibility of any teacher.

\subsection{Open Philosophically-Oriented Questions}

Dialogical praxis occurs differently according to whether participants are adults 
or children (Chesters \& Hinton, 2017). In the following paragraph we suggest guidelines for teachers to facilitate dialogical critical exchanges among young pupils.

Several authors have suggested ways to facilitate philosophical or critical dialogues with pupils (among others: Buckley et al., 2015; Cam, 2008; Canuto, 2015; Lipman et al., 1980; McComas \& Abraham, 2004): In order to encourage pupils' interest during the exchange, the teacher prepares a discussion plan to challenge and answer the questions pupils posed beforehand; the discussion plan does not orient pupils toward one outcome or another, but rather helps them progress in their comprehension of the meanings of the concepts; the discussion plan reflects a progression in questions that range from the most concrete to the more conceptual; questions posed are likely to arouse the pupils' curiosity and to generate cognitive conflicts in their minds; wording of the questions must be adapted to the pupils' age group; questions must be meaningful for pupils and take into consideration their daily experience; questions can be preceded or followed by a game (for the younger ones) or an intellectual exercise (for the older ones); the teacher encourages the participation of all pupils without insisting if a pupil wishes to remain silent; the teacher follows up with questions to help pupils transcend their initial statement; the teacher encourages pupils to talk to each other directly (dialogue) instead of simply answering the teacher's questions (monologue); the teacher encourages pupils to listen to each other actively and caringly, to question each other and to support, complete, clarify, nuance, and criticize peers' points of view; the teacher gives pupils time to think before answering; the teacher makes sure pupils have fun and increase their self-esteem during dialogical critical praxis.

More specifically, we suggest questions oriented toward stimulating the epistemological perspectives and thinking modes inherent in DCT (Daniel, 2013). To stimulate logical thinking: How is your point of view related to the question being discussed?; Can you reformulate your idea so it can help us progress?; Why do you say that ...?; When you say ... what are you basing your statement on?. To stimulate creative thinking: What would happen if ...?; Can you illustrate what you are saying with an example?; Who can provide a counter-example?; Who has another point of view on the question?. To stimulate responsible thinking: What would happen if everyone did $x$ (action, gesture ...)?; Is $x$ (behaviour, point of view, value ...) acceptable in all contexts?; Is $x$ (behaviour, rule, value ...) useful to many people?; What are the consequences of $X$ (point of view, decision, behavior ...) for you? for others? for society?. To stimulate metacognitive thinking: What are we doing right now (on the cognitive, discursive or social level)?; Do you want to modify your point of view after hearing your peers' points of view?; Did we philosophize today?; What thinking skills were mobilized during our exchange?.

Also, following are some examples of teacher's questions to increase epistemological complexity in pupils' thinking. For post-egocentricity and pre-relativism (toward generalizations): Does what you say about $x$ (i.e.: your dog) apply 
to all $x$ (i.e.: all $\mathrm{dogs})$ Does it apply to all $y$ (i.e.: all animals)? Does it apply to all $z$ (i.e.: all living beings)?. For relativism (toward convergent relationships): Do you agree with the idea expressed by $X$ ?; In relation with what $X$ just said, do you think that ...?; Who wants to pursue $X$ s idea?. For post-relativism and intersubjectivity (toward evaluative relationships): Who can expand on ...?; What are the advantages and disadvantages of such an action, tradition, value ...?; What are the positive and negative aspects of such a point of view, of such an action?; Among the criteria we have just mentioned, which seems the most reliable, appropriate or useful?

\subsection{Future Directions}

This research should be expanded upon with similar research projects that would compare the incidence of closed questions and open philosophicallyoriented questions on different groups of pupils that are academically strong and academically weak; who come from different socio-economic backgrounds; who attend different types of schools (private, public). It would also be relevant to verify these results in the long term, for example, to look at which epistemologies groups of pupils are situated in after one year of philosophical praxis. And, within these groups, it would also be relevant to study the impact of the teachers' questions on the types of questions posed by the pupils themselves during their exchanges, and to verify the type of verbal exchanges (anecdotal, monological, non-critical dialogical, semi-critical dialogical, critical dialogical) that each type of question elicits. It would be worth examining pupils' written reflections. Finally, the whole question of teacher training (initial and continued) has yet to be fully explored.

\section{References}

AACU (2002). Greater Expectations: A New Vision for Learning as a Nation Goes to College. Report of the Association of American Colleges and Universities, Washington DC.

AACU (2007). College Learning for the New Global Century. Report of the Association of American Colleges and Universities, Washington DC.

Ali-Sheir, A., Abdel-Khal, W. M., \& El Nabawy, E. (2014). Oral Questioning Technique for Developing Critical Thinking Skills in EFL Classroom. Educational Sciences Journal, 22, 1-23.

Arends, R. (1994). Learning to Teach. New York: McGraw-Hill Inc.

Auriac-Peyronnet, E., \& Daniel, M.-F. (2002). The Specifics of Philosophical Dialogue: A Case Study of Pupils Aged 11 and 12 Years. Thinking, 16, 23-31.

Auriac-Peyronnet, E., \& Daniel, M.-F. (2009). Apprendre à dialoguer avec des élèves: Le cas des dialogues philosophiques (Learning to Dialogue with Pupils: The Case of Philosophical Dialogues). Psychologie de l'Interaction, 25-26, 155-196.

Auriac-Slusarczyk, E., \& Colletta, J.-M. (Eds.) (2015). Les ateliers de philosophie: Une pensée collective en acte (Workshops of Philosophy: Collective Thinking in Action). Clermont-Ferrand, France: Presses universitaires Blaise-Pascal.

Barth, B.-M. (2008). De la pratique à la théorie: Apprendre à construire son savoir (From Practice to Theory). In C. Leleux (Ed.), La philosophie pour enfants. Le modèle de 
Matthew Lipman en discussion (Philosophy for Children. Discussion about Matthew Lipman's Model). Brussels: De Boeck.

Baumfield, V. (2015). Tools for Inquiry: The Role of Thinking Skills Approaches in Developing Pedagogy as Theory. In R. Wegerif, L. Li, \& J. Kaufman (Eds.), International Handbook on Research on Teaching Thinking (pp. 71-79). London: Routledge.

Baumfield, V. (2017). Changing Minds. The Professional Learning of Teachers in a Classroom Community of Inquiry. In M. Gregory, J. Haynes, \& K. Murris (Eds.), The Routledge International Handbook of Philosophy for Children (pp. 119-126). London and New York: Routledge.

Belghiti, K., El Kirat, Y., \& Chana, M. (2016). Critical Thinking Development: The Case of the English Course in the CPGE Classes in Meknes, Fes and Kenitra. Arab Society of English Language Studies Annual Conference Proceedings, 2016 Mohammed V University of Rabat, Morocco, 106-127.

http://awej.org/index.php?option=com_content\&view=article\&id=1073:karima-belghit i-yamina-el-kirat-el-allame-mohamed-chana\&catid=71\&Itemid=134

Berland, L., \& McNeill, K. (2010). A Learning Progression for Scientific Argumentation: Understanding Student Work and Designing Supportive Instructional Contexts. Science Education, 94, 765-793.

Bouchard, N. (2002). L'approche reconstructive. Pour éduquer à la reconnaissance des personnes [The Reconstructive Approach. Education to Others's Recognition]. In N. Bouchard (Ed.), Pour un renouvellement des pratiques d'éducation morales: six approches contemporaines (To a Renewal of Moral Education Practices: Six Contemporary Approaches) (pp. 171-196). Montreal: PUQ.

Bourdon, R. (2008). Le relativisme (Relativism). Paris: Presses Universitaires de France.

Bourgeault, G. (2012). Éthique professionnelle et réflexivité: Quelle connivence? (Professional Ethics and Reflectivity: Which Convergence?) In M. Tardif, C. Borges, \& A. Malo (Eds.), Le virage réflexif en éducation. Où en sommes-nous 30 ans après Schön? (Reflective Change in Education. Where Are We 30 Years after Schön?). Brussels: De Boeck.

Bressoux, P., \& Dessus, P. (2003). Stratégies de l'enseignant en situation d'interaction (Teacher's Strategies in Interactive Situations). In M. Kail, \& M. Fayol (Eds.), Les sciences cognitives et l'école. La question des apprentissages (Cognitive Sciences and School. Question about Learning) (pp. 213-257). Paris: Presses universitaires de France.

Bressoux, P., Amigues, R., Arnoux, M., Barré-De Miniac, C., Clanet, J., Dessus, P., Halté, J.-F., Maurice, J.-J., Perrin-Glorian, M.-J., \& Raby, F. (2002). Les stratégies de Penseignant en situation d'interaction (Teacher's Strategies in Interactive Situations). Programme Ecole et Sciences Cognitives, Report, February 2002.

Brookhart, S. (2016). Start with Higher-Order Thinking. Educational Leadership, 74, 10 15.

Buckley, J., Archibald, T., Hargraves, M., \& Trochim, W. (2015). Defining and Teaching Evaluative Thinking: Insights from Research on Critical Thinking. American Journal of Evaluation, 36, 375-388. https://doi.org/10.1177/1098214015581706

Butler, C. (Ed.) (2012). Child Rights. The Movement, International Law, and Opposition. West Lafayette, IN: Purdue University Press.

Cam, P. (2008). Twenty Thinking Tools. Victoria: ACER Press.

Canuto, A. (2015). Reflections on Theory and Pedagogy of Challenges in Facilitating Children's Dialogues in a Community of Inquiry. International Journal of Whole Schooling, 11, 1-15.

Chesters, S., \& Hinton, L. (2017). What's Philosophy Got to Do with It? Achieving Syn- 
ergy between Philosophy and Education in Teacher Preparation. In M. Gregory, J. Haynes, \& K. Murris (Eds.), The Routledge International Handbook of Philosophy for Children (pp. 208-215). London and New York: Routledge.

Colley, C., \& Windschiti, M. (2016). Rigor in Elementary Science Students' Discourse: The Role of Responsiveness and Supportive Conditions for Talk. Science Education, 100, 1009-1038. https://doi.org/10.1002/sce.21243

Cotton, K. (1988). Classroom Questioning. Office of Educational Research and Improvement (OERI), New Jersey, US: Northwest Regional Educational Laboratory.

Critelli, A., \& Tritapoe, B. (2010). Effective Questioning Techniques to Increase Class Participation. E-Journal of Student Research, 2, 1-7.

Curenton, S. (2016). Conversation Compass: A Teachers' Guide to High Quality Language Learning in Young Children. St. Paul, MN: Redleaf Press.

Daniel, M.-F. (2000). From Talking to Dialogue. Critical and Creative Thinking, 8, 1-7.

Daniel, M.-F. (2013). Relativism: A Threshold for Pupils to Cross in Order to Become Dialogical Critical Thinkers. Childhood \& Philosophy, 9, 43-62.

http://periodicos.proped.pro.br/index.php/childhood/issue/view/64

Daniel, M.-F., \& Delsol, A. (2005). Learning to Dialogue in Kindergarten. A Case Study. Analytic Teaching, 25, 23-52.

Daniel, M.-F., \& Fiema, G. (in press). Dialogical Critical Thinking in Children. Knowledge Cultures.

Daniel, M.-F., \& Gagnon, M. (2011). Developmental Process of Dialogical Critical Thinking in Groups of Pupils Aged 4 to 12 Years. Creative Education, 2, 418-428.

http://www.scirp.org/Journal/PaperInformation.aspx?paperID $=8854$

https://doi.org/10.4236/ce.2011.25061

Daniel, M.-F., \& Gagnon, M. (2016). Dialogical Critical Thinking with 5 to 12 Years Old Pupils: A Continuous Epistemological Development. In G. Gibson (Ed.), Critical Thinking: Theories, Methods and Challenges (pp. 45-76). New York: Nova Science Publishers Inc.

Daniel, M.-F., Lafortune, L., Pallascio, R., Splitter, L., Slade, C., \& De la Garza, T. (2005). Modeling the Development Process of Dialogical Critical Thinking in Pupils Aged 10 to 12 Years. Communication Education, 54, 334-354.

http://www.tandfonline.com/toc/rced20/54/4

https://doi.org/10.1080/03634520500442194

Daniel, M.-F., Pettier, J.-C., \& Auriac, E. (2011). The Incidence of Philosophy on Discursive and Language Competencies of Pupils Aged Four Years. Creative Education, 2, 296-304.

http://www.scirp.org/Journal/PaperInformation.aspx?paperID $=6707$

https://doi.org/10.4236/ce.2011.23041

Dewey, J. (1960). How We Think. Boston, MA: Heath and Co.

Dewey, J. (1983). Démocratie et éducation, Introduction à la philosophie de léducation (Democracy and Education. Introduction to the Philosophy of Education). Artigues-près-Bordeaux, Éditions L'Age d'Homme.

El Kirat, Y., \& Belghiti, K. (2014). Conditioning Factors for Critical Thinking in Moroccan Higher Education: The Case of Moroccan EFL University Students. Le rôle de la pensée critique dans léducation, la formation et la recherche académique. (The Role of Critical Thinking in Education, Formation and Academic Research). Proceedings. Colloques et Seminaires (Colloquiums and Seminars), (182), 21-46.

Fabre, M., \& Gohier, C. (Eds.) (2015). Les valeurs éducatives au risque du néo-libéralisme (The Educative Values and the Risk Inherent in Neo-Liberalism). Rouen, France: 
Presses universitaires de Rouen et du Havre.

Fasco, D. (1994). Questioning and Thinking. Inquiry: Critical Thinking across Disciplines, 14, 43-47.

Forges, R. (2013). Formation initiale des enseignants en enseignement de l'éducation physique et à la santé: Étude des manifestations d'une pensée critique visée, stimulée et manifestée (Teachers' Initial Formation in Teaching Physical Education: Study of the Manifestations of an Aimed, Stimulated and Expressed Critical Thinking). Doctoral Thesis, Montreal, Canada: Université de Montréal.

Francis, E. (2016). Now, That's a Good Question! How to Promote Cognitive Rigor through Classroom Questioning. Alexandria, VA: ASCD.

Freire, P. (1974). Pédagogie des opprimés (Pedagogy of the Oppressed). Paris: Maspéro.

Galichet, F. (2002). La citoyenneté comme pédagogie: Réflexions sur l'éducation à la citoyenneté (Citizenship as Pedagogy: Reflexions on Civic Education). Revue des Sciences de l'Éducation (Journal of Sciences Education), 28, 105-124.

https://doi.org/10.7202/007151ar

Galichet, F. (2012). Quelle éducation civique et morale aujourd'hui? (Today, Which Civic and Moral Education?). BLÉ, 91, 10-11.

Gallagher, J., \& Aschner, M. (1963). A Preliminary Report on Analysis of Classroom Interaction. Merrill-Palmer Quarterly of Behavior and Development, 9, 183-194.

Golding, C. (2009). “That's a Better Idea!” Philosophical Progress and Philosophy for Children. Childhood \& Philosophy, 5, 223-269.

Haynes, J., \& Murris, K. (2011). The Provocation of an Epistemological Shift in Teacher Education through Philosophy for Children. Journal of Philosophy of Education, 4, 285-303. https://doi.org/10.1111/j.1467-9752.2011.00799.x

Ikuenobe, P. (2001). Questioning as an Epistemic Process of Critical Thinking. Educational Philosophy and Theory, 33, 325-341. https://doi.org/10.1111/j.1469-5812.2001.tb00274.x

Karabulut, U. S. (2012). How to Teach Critical Thinking in Social Studies Education: An Examination of Three NCSS Journals. Eurasian Journal of Educational Research, 49, 197-214.

King, A. (1994). Guiding Knowledge Construction in the Classroom: Effects of Teaching Children How to Question and How to Explain. American Educational Research Journal, 31, 338-368. https://doi.org/10.3102/00028312031002338

Kohan, W. (2011). Childhood, Education and Philosophy: Notes on Deterritorialisation. Journal of Philosophy of Education, 45, 339-357. https://doi.org/10.1111/j.1467-9752.2011.00796.x

Kpazaï, G. (Ed.) (2015). Pensée critique et innovations dans la formation universitaire (Critical Thinking and Innovation at University Level). Montreal: Éditions Peisaj, collection "Cogito".

Kwak, D. (2007). Re-Conceptualizing Critical Thinking for Moral Education in Culturally Plural Societies. Educational Philosophy and Theory, 39, 460-470. https://doi.org/10.1111/j.1469-5812.2007.00353.x

Lacroix, A. (2010). Éduquer à la citoyenneté et contribuer à la formation du jugement moral (To Educate to Citizenship and to Contribute to the Development of Moral Judgment). In F. Jutras (Ed.), L'éducation à la citoyenneté. Enjeux socioéducatifs et pédagogiques (Civic Education. Socioeducative and Pedogogical Stakes) (pp. 89-109). Quebec: PUQ.

Lechasseur, K. (2015). Modélisation de la mobilisation des savoirs par une pensée critique chez des étudiantes en sciences infirmières lors de stages cliniques (Modelization of the 
Mobilized Knowledge by Means of Critical Thinking in Students during Their Internship in Nursing). In G. Kpazaï (Ed.), Pensée critique et innovations dans la formation universitaire (Critical Thinking and Innovation at University Level) (pp. 109-137). Montreal: Éditions Peisaj.

Lenoir, Y. (2016). Quelles seraient les finalités éducatives scolaires dans le monde actuel? (What Would Be the Educative Aims in the Actual World?) Conférence d'ouverture (Keynote). Forum Synergie 2016. Hotel Admiral Raidsson: Toronto (November 30).

Leroux, G. (2016). Différence et liberté. Enjeux actuels de Péducation au pluralisme (Difference and Freedom. Actual Stakes in Education to Pluralism). Montreal: Boréal.

Lévine, J., Chambart, G., \& Sillam, M. (2004). Essai sur le monde philosophique de Penfant. Le dialogue moi monde-instance monde (Essay on the Child's Philosophical World. Dialogue with Self, World-Instance, World). Brussels: French Parliament of Brussels. AGSAS website.

Lipman, M. (2003). Thinking in Education. Cambridge: Cambridge University Press. https://doi.org/10.1017/CBO9780511840272

Lipman, M., Sharp, A. M., \& Oscanyan, F. (1980). Philosophy in the Classroom. Philadelphia, PA: Temple University Press.

Marceau, E. (2010). L'éducation à la citoyenneté à l'école. Une réponse de l'école au problème du vivre-ensemble (School Education to Citizenship. An Answer from School to the Problem of Living Together). In F. Jutras (Ed.), L'éducation à la citoyenneté. Enjeux socioéducatifs et pédagogiques (Civic Education. Socioeducative and Pedogogical Stakes) (pp. 77-88). Quebec: PUQ.

Margutti, P. (2006). “Are You Human Beings?” Order and Knowledge Construction through Questioning in Primary Classroom Interaction. Linguistics and Education, 17, 313-346.

Martin, A., \& Hand, B. (2009). Factors Affecting the Implementation of Argument in the Elementary Science Classroom. A Longitudinal Case Study. Research in Science Education, 39, 17-38. https://doi.org/10.1007/s11165-007-9072-7

McComas, W., \& Abraham, L. (2004). Asking More Effective Questions (pp. 1-16). Rossier School of Education.

Melo-Leon, J. (2015). A Baseline Study of Strategies to Promote Critical Thinking in the Preschool Classroom. Education and Learning Research Journal, 10, 113-127.

Meyer, S., Marsick, V., King, K., \& Lawler, P. (2003). Professional Development in Corporate Training. New Directions for Adult \& Continuing Education, 98, 75-82. https://doi.org/10.1002/ace.102

Michalko, M. (2006). Thinkertoys: A Handbook of Creative Thinking Techniques. Berkeley, CA: 10 Speed Press.

Murris, K. (2013). The Epistemic Challenge of Hearing Child's Voice. Studies in Philosophy and Education, 32, 245-259. https://doi.org/10.1007/s11217-012-9349-9

Nussbaum, M. (2004). Emotions as Judgments of value and Importance. In R. Solomon (Ed.), Thinking about Feelings: Contemporary Philosophers on Emotions (pp. 183-199). New York: Oxford University Press.

Paul, R. (1992). Critical Thinking: What Every Person Needs to Survive in a Rapidly Changing World. Santa Rosa, CA: Foundation for Critical Thinking.

Pettier, J.-C. (2015). Développer la pensée critique en formation en dynamisant la formation par l'organisation de sa critique (To Develop Critical Thinking in Dynamizing the Formation by the Organisation of One's Critique). In G. Kpazaï (Ed.), Pensée critique et innovations dans la formation universitaire (Critical Thinking and Innovation at University Level) (pp. 83-99). Montreal: Éditions Peisaj. 
Rispail, M. (2007). Rôle de l'enseignant dans l'atelier de philosophie (The Teacher's Role in the Workshops of Philosophy). In M. Rispail (Ed.). Apprendre à parler, apprendre à penser. Les ateliers de philosophie (Learning to Talk and to Think. The Workshops of Philosophy) (pp. 77-98). Paris: Sceren; Nice: Éditions du Centre Régional de Documentation Pédagogique.

Schwarz, B., \& Slakmon, B. (2015). Becoming a Questioner in a Philosophy Class. In R. Wegerif, L. Li, \& J. Kaufman (Eds.), The Routledge International Handbook of Research on Teaching Thinking (pp. 457-467). London and New York: Routledge.

Smart, J., \& Marshall, J. (2013). Interactions between Classroom Discourse, Teacher Questioning, and Student Cognitive Engagement in Middle School Science. Journal of Science Teacher Education, 24, 249-267. https://doi.org/10.1007/s10972-012-9297-9

Smith, V., \& Szymanski, A. (2013). Critical Thinking: More than Test Scores. NCPEA International Journal of Educational Leadership Preparation, 8, 16-26.

Sorsana, C., \& Troadec, B. (2007). Facteurs socio-culturels et développement cognitif (Sociocultural Factors and Cognitive Development). In A. Blaye, \& P. Lemaire (Eds.), Psychologie du développement cognitif de Penfant (Psychology of the Child's Cognitive Development) (pp. 283-313). Brussels: Éditions De Boeck Université.

Tallent, R., \& Barnes, J. (2015). Think Bubbles and Socrates: Teaching Critical Thinking to Millennials in Public Relations Classes. Universal Journal of Educational Research, 3, 435-441. https://doi.org/10.13189/ujer.2015.030702

Tardif, M. (2012). Réflexivité et expérience du travail enseignant (Reflectivity and the Teachers' Experience). In M. Tardif, C. Borges, \& A. Malo (Eds.), Le virage réflexif en éducation. Où en sommes-nous 30 ans après Schön? (Reflective Change in Education. Where Are We 30 Years after Schön?). Brussels: De Boeck.

UNESCO (2007). Philosophy, a School of Freedom-Teaching Philosophy and Learning to Philosophize: Status and Prospects. Paris: UNESCO.

UNESCO (2015). Repenser l'éducation. Vers un bien commun mondial? (Rethinking Education. Towards a Global Common Good?). Paris: UNESCO.

Weber, B., \& Wolf, A. (2017). Questioning the Question. A Hermeneutical Perspective on the "Art of Questioning" in a Community of Philosophical Inquiry. In M. Gregory, J. Haynes, \& K. Murris (Eds.), The Routledge International Handbook of Philosophy for Children (pp. 74-83). London and New York: Routledge.

Wertsch, J. (1997). Vygotsky and the Formation of the Mind. Cambridge, MA: Harvard University Press.

Wilen, W. (1991). Questioning Skills for Teachers. What Research Says to the Teacher (3rd ed.). Washington DC: National Education Association.

Winstanley, C. (2008). Philosophy and the Development of Critical Thinking. In M. Hand, \& C. Winstanley (Eds.), Philosophy in Schools (pp. 105-118). New York: Continuum International. 


\section{Appendix A. Operational Model of the Developmental Process of DCT}

\begin{tabular}{|c|c|c|c|c|}
\hline $\begin{array}{c}\text { MODE/ } \\
\text { EPISTEMOLOGICAL } \\
\text { PERSPECTIVE }\end{array}$ & LOGICAL & CREATIVE & RESPONSIBLE & METACOGNITIVE \\
\hline EGOCENTRICITY & $\begin{array}{l}\text { Statement based on the } \\
\text { perceptual experience of a } \\
\text { specific and personal fact. }\end{array}$ & $\begin{array}{l}\text { Statement that gives } \\
\text { meaning to a personal } \\
\text { and concrete point of } \\
\text { view. }\end{array}$ & $\begin{array}{l}\text { Statement that is related } \\
\text { to a personal and specific } \\
\text { behaviour tied to a social } \\
\text { or moral belief. }\end{array}$ & $\begin{array}{l}\text { Retrospective statement } \\
\text { about a personal and } \\
\text { specific task, point of } \\
\text { view, feeling, etc. }\end{array}$ \\
\hline POST-EGOCENTRICITY & $\begin{array}{l}\text { Statement based on experience } \\
\text { (personal or someone close) }+ \\
\text { reasoning. }\end{array}$ & $\begin{array}{l}\text { Statement that gives } \\
\text { meaning to a personal } \\
\text { point of view (but } \\
\text { distanced from self). }\end{array}$ & $\begin{array}{l}\text { Particular/concrete } \\
\text { statement tied to a moral } \\
\text { or social rule (learned). } \\
\text { Not contextualized. }\end{array}$ & $\begin{array}{l}\text { Retrospective statement } \\
\text { about a personal task, } \\
\text { point of view, feeling, etc. } \\
\text { (distanced from self). }\end{array}$ \\
\hline PRE-RELATIVISM & $\begin{array}{l}\text { Somewhat generalized statement } \\
\text { that is not justified or with an } \\
\text { implicit, circular or false } \\
\text { justification. }\end{array}$ & $\begin{array}{l}\text { Statement that is new, } \\
\text { divergent or that presents } \\
\text { different situations/ } \\
\text { solutions/hypotheses } \\
\text { (units) in relation to a } \\
\text { personal idea or to } \\
\text { someone else's idea (peer } \\
\text { or text). }\end{array}$ & $\begin{array}{l}\text { Statement linked to a } \\
\text { somewhat generalized } \\
\text { action in a moral or } \\
\text { social perspective. }\end{array}$ & $\begin{array}{l}\text { Descriptive retrospective } \\
\text { of a personal task, point } \\
\text { of view, feeling, etc. } \\
\text { (distanced from self). }\end{array}$ \\
\hline RELATIVISM & $\begin{array}{l}\text { Incomplete or concrete } \\
\text { justification } \\
\text { (explanation)/reasoning based } \\
\text { on experience. }\end{array}$ & $\begin{array}{l}\text { Relationship that gives } \\
\text { meaning to a peer's point } \\
\text { of view (by completing it } \\
\text { or adding a nuance). }\end{array}$ & $\begin{array}{l}\text { Statement that explains a } \\
\text { will to understand/ } \\
\text { include others (from the } \\
\text { immediate environment). } \\
\text { (Contextualized). }\end{array}$ & $\begin{array}{l}\text { Descriptive/explanatory } \\
\text { retrospective of another } \\
\text { person's task, thought, } \\
\text { etc. (immediate } \\
\text { environment). }\end{array}$ \\
\hline $\begin{array}{l}\text { POST-RELATIVISM/ } \\
\text { PRE-INTERSUBJECTIVITY }\end{array}$ & $\begin{array}{l}\text { Justification based on "good } \\
\text { reasons"/simple reasoning. }\end{array}$ & $\begin{array}{l}\text { Relationship that } \\
\text { presents a different } \\
\text { context that takes into } \\
\text { account the group's } \\
\text { perspective. }\end{array}$ & $\begin{array}{l}\text { Statement that justifies a } \\
\text { desire to understand/ } \\
\text { include others (distant } \\
\text { environment). } \\
\text { (contextualized) }\end{array}$ & $\begin{array}{l}\text { Descriptive/ } \\
\text { explanatory retrospective } \\
\text { of another person's task, } \\
\text { thought, etc. (distant } \\
\text { environment). }\end{array}$ \\
\hline \multirow[t]{2}{*}{ INTERSUBJECTIVITY } & $\begin{array}{l}\text { Justification based on criteria. } \\
\text { Conceptualization based on } \\
\text { evaluative reasoning. }\end{array}$ & $\begin{array}{l}\text { Evaluative relationship } \\
\text { that provides a different } \\
\text { meaning and transforms } \\
\text { the perspective. }\end{array}$ & $\begin{array}{l}\text { Doubt that underlies the } \\
\text { evaluation of categories } \\
\text { (rules, principles, } \\
\text { social/moral values). }\end{array}$ & $\begin{array}{l}\text { Evaluative statement that } \\
\text { expresses a change in } \\
\text { perspective following the } \\
\text { integration of criticism. }\end{array}$ \\
\hline & Conceptualization & Transformation & Categorization & Correction \\
\hline
\end{tabular}


Submit or recommend next manuscript to SCIRP and we will provide best service for you:

Accepting pre-submission inquiries through Email, Facebook, LinkedIn, Twitter, etc. A wide selection of journals (inclusive of 9 subjects, more than 200 journals)

Providing 24-hour high-quality service

User-friendly online submission system

Fair and swift peer-review system

Efficient typesetting and proofreading procedure

Display of the result of downloads and visits, as well as the number of cited articles Maximum dissemination of your research work

Submit your manuscript at: http://papersubmission.scirp.org/

Or contact ce@scirp.org 